\title{
REDD+ Implementation in Community-Based Muyong Forest Management in Ifugao, Philippines
}

\author{
Ram Avtar ${ }^{1, *} \mathbb{D}$, Kenichi Tsusaka ${ }^{2}$ and Srikantha Herath ${ }^{3}$ \\ 1 Faculty of Environmental Earth Science, Hokkaido University, Sapporo 060-0810, Japan \\ 2 Institute for the Advanced Study of Sustainability (UNU-IAS), United Nations University, Tokyo 150-8925, \\ Japan; tsusakak@gmail.com \\ 3 Ministry of Megapolis and Western Development, Battaramulla 10120, Sri Lanka; herath.unu@gmail.com \\ * Correspondence: ram@ees.hokudai.ac.jp; Tel.: +81-011-706-2261
}

Received: 3 September 2019; Accepted: 1 November 2019; Published: 5 November 2019

\begin{abstract}
Ifugao province of the Philippines has a traditional muyong forest system that supplies water and prevents soil erosion of the world-famous Ifugao rice terraces. The socio-political structure of Ifugao has been the key to the maintenance and communal use of land, as well as the muyong forest, without causing excessive damage to the land. Recently, the Ifugao is facing various challenges viz. deforestation, slash-and-burn, introduction of commercial rice, and climate change. The aim of the study is to qualitatively assess the forest management practices in the muyong forest and the way forward to implement the United Nations-Reducing Emissions from Deforestation and Forest Degradation (REDD+) mechanism. Community forestry can be an interesting option to reduce $\mathrm{CO}_{2}$ emissions from deforestation in Ifugao. This study qualitatively explores the societal problems in the area using focus group discussion (FGD) and key informant interviews (KII). The results show that the terracing lifestyle is at risk, due to mounting economic pressures from the domestic economy. Societal changes are altering the perceptions of the youth in terms of muyong sustainable management. They are threatening the sustainability of the terraces in the long-term because of outward migration and less value given to traditional practices. Furthermore, integration of commercial rice is changing the traditional agricultural system and placing less focus on forest maintenance. This study also discusses potential challenges and opportunities of REDD+ intervention and the role of REDD+ to foster sustainable muyong forest management as well as to find new innovative ways to maintain the Ifugao traditional system while coping with the modernization of the Ifugao economy.
\end{abstract}

Keywords: Ifugao; REDD+; rice terraces; muyong; community farming

\section{Introduction}

Forest ecosystems constitute an extremely important carbon reservoir and provide various resources to millions of people [1-4]. According to the Forest Resources Assessment Report 2015, the total forest area of the Philippines is 8.4 million hectares, with total above-ground biomass stock in forests and other woodland of about 1160 million tons [5]. Additionally, the Philippines is one of seventeen mega diverse countries. There is an enormous potential for forests in the Philippines to become a meaningful carbon sink if reforestation or a reduction in deforestation efforts are continued [6].

The country is in the midst of an unprecedented level of economic growth that will undoubtedly apply pressure on rural communities, particularly those who rely on subsistence agriculture [6]. There is a clear relationship between higher Gross Domestic Product (GDP) and having a smaller agricultural population, around the world $[7,8]$. Countries like the United States and Japan, which once were more agro-based, have transitioned to non-agro-based and service-based economies where farmers no longer make up the majority of the labor force [8]. This labor transition can be argued to be due 
to economic development and increased GDP, which leads to improved efficiency and technological development [9]. The Philippines is still an agricultural-based economy because of the presence of a large agriculture sector.

The Philippines is one of the most vulnerable countries in the Southeast Asian region as it is prone to climate hazards, which is evident in recent disasters such as Typhoon Ketsana in 2009, Haiyan in 2013, and Mangkhut in 2018. International funding for climate change initiatives in the Philippines is geared toward adaptation activities [10]. Climate change is likely to have a large impact on agriculture production as well as on the welfare of people [11]. Nations that have not reached the development of a higher agricultural population (whose livelihoods depend on agriculture) and less economic resources are not only at the risk of climate change but also in need of further analysis to ensure that widespread impacts are reduced and controlled in the future [12].

The province of Ifugao is located in the heart of the Philippine Cordilleras, a landlocked region located within the northern island of Luzon. The rice terraces, which have been managed for over 2000 years, are traditional cultural and spiritual practices of the local population [13]. They serve as tourist attractions for both international and domestic tourists which have brought large economic growth to rural communities in the Ifugao [14]. The traditional rice cultivation system of Ifugao is now threatened by natural and anthropogenic factors. In the highland area, the rice terraces are supported by an accompanying forest management system that feeds into the rice terrace system. It is known as muyong forest by the local people of the Philippines $[15,16]$. The local definition of "muyong" is a privately owned and managed woodlot situated above the rice terraces.

The Ifugao forest maintenance system is a socio-political structure [17] which is an intertwined connection of its religion, philosophy, and community members [18]. Rice is not only considered a staple food of the Philippines diet, but also a symbol of national identity [19]. The muyong system provides vital regulatory services to the rice terraces by supplying stable water. The local people are familiar with traditional practices and customs, and understand the importance of muyong and that it, therefore, must be taken care of. Maintaining the muyong forest system can be a viable tool by providing mitigation and adaptation measures. Additionally, afforestation can prevent soil erosion and increase soil stability. This can help to reduce the risk of landslides, which are extremely common during periods of high rainfall. The muyong system is built on traditional forest management systems to protect muyong forests while improving the livelihoods of local people. The widespread application of the muyong system aligns itself well within the objectives of the UN-REDD+ program. The use of community-based forest management (CBFM) practices under REDD+ appears to reduce deforestation and forest degradation and provide livelihoods. The previous studies demonstrate that CBFM plays a central role in REDD+ initiatives and there is a huge potential of REDD+ in the Philippines [20-22]. The CBFM program in the Philippines was launched in 1995 with the aim to ensure sustainable forest management. Thus, the various land tenure systems were issued to individuals to democratize their access to the public land [23]. The Philippines' governance expected that the improved socio-economic condition would lead to improved management of natural resources [23]. The muyong forest-based living is the best option for the local people who live nearby or in the muyong to earn their livelihood. Thus, the REDD+ mechanism can be implemented with the support of the local community people because both share the common objective to manage forests sustainably [24].

An increasing human population led to increased demand for firewood and timber products for housing and woodcarvings, causing deforestation and affecting water supply from the muyong [16]. An increase in slash-and-burn agriculture activities in the Ifugao province has had a negative impact on muyong forests. Moreover, an increase in deforestation and forest degradation of the muyong forests cause $\mathrm{CO}_{2}$ emissions and changes in the hydrological cycle of rice terraces [15]. The objective of this study was to qualitatively assess the situation of Ifugao rice terraces and the muyong system under the REDD+ framework in order to identify reasons for REDD+ intervention that could be beneficial for the area. This research will also provide new innovative ways to maintain the muyong forest 
system through REDD+ and the CBFM to reduce carbon emissions and improve the livelihood of the community's people.

\section{Study Area}

The study area is the barangay of Nagacadan, which is shown in Figure 1. Nagacadan is one of 14 barangays in the municipality of Kiangan, located within the Ifugao province of the Philippines. Figure 1 also shows the land use/land cover map of the study site, which is mostly covered with muyong and bilid forest and paddy (rice-terraces) areas.

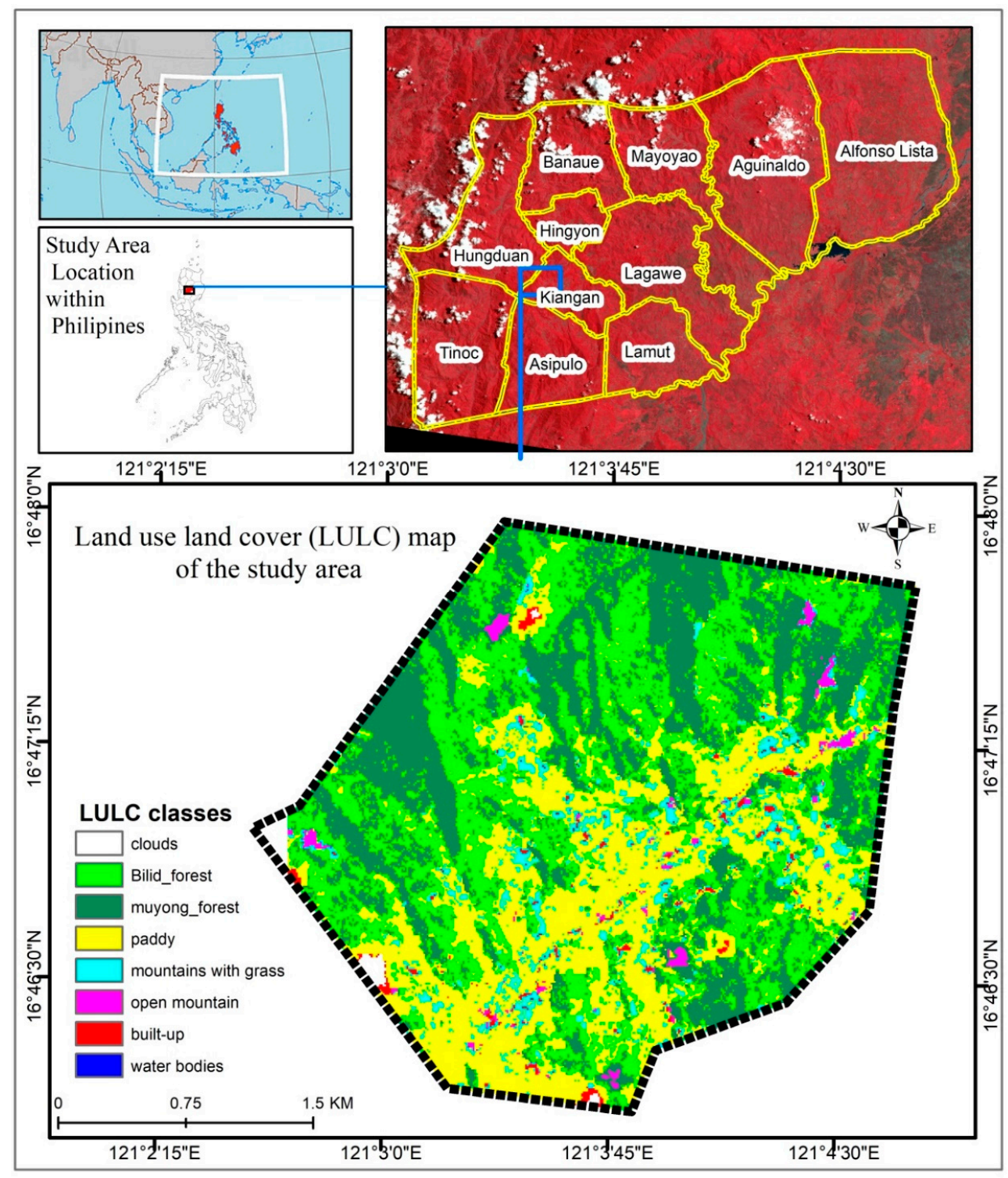

Figure 1. Location of the study area.

Nagacadan is located approximately $16^{\circ} 44^{\prime} 21^{\prime \prime} \mathrm{N}$, latitude and $121^{\circ} 4^{\prime} 4^{\prime \prime}$ E longitude with an elevation between $500-1100 \mathrm{~m}$ above sea level. It consists of five community hamlets viz. Bayninan, Wingyon, Onnop, Pau, and Bilong. The forests in the area are classified as a mix between mossy forest, pine forest, and dipterocarp forest [25]. Previous studies have established eight broad categories that have been able to encompass these varied land uses: (1) grassland, (2) cane land, (3) forest, (4) private woodlots, (5) swidden fields, (6) housing stands, (7) drained fields, and (8) rice terraces [26]. A typical landscape view of Ifugao rice terraces and muyong forest is shown in Figure 2. 


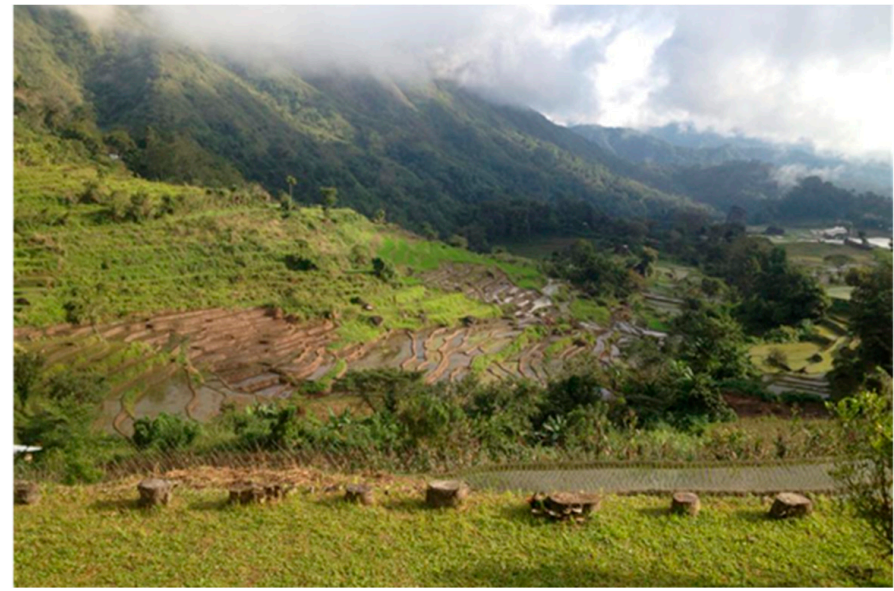

(a)

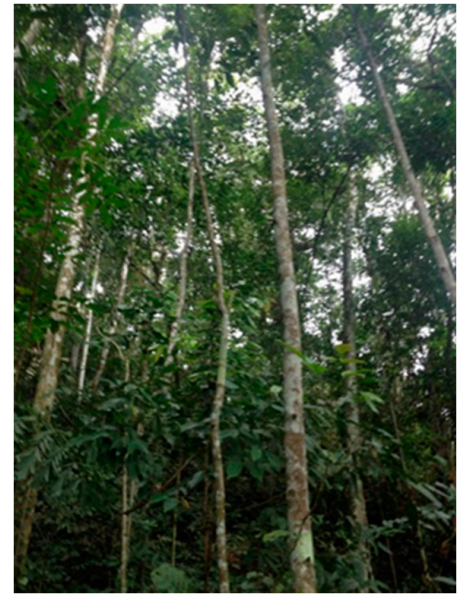

(b)

Figure 2. A typical landscape view of Ifugao rice terraces (a) and muyong forest (b).

Despite being the second smallest province in the Cordilleras Administrative Region in terms of land area, Ifugao is one of the most densely populated. It features a population of 191,078 (2010), which, corresponding to its total area of $2628.21 \mathrm{~km}^{2}$ makes it the second most densely populated province in the Cordilleras Administrative Region. The study site of Nagacadan consists of approximately 8410 hectares of land area, and is governed by three administrative divisions, the largest being the Cordilleras Administrative Region, followed by the provincial government of Ifugao, and the municipality of Kiangan [27].

The Philippines has a tropical climate, although weather patterns consist primarily of rainy and dry seasons. The average temperature in Ifugao is cooler than other places in the country, averaging $24^{\circ} \mathrm{C}$ around December-January to $29.5^{\circ} \mathrm{C}$ in June. The rainy season in Ifugao typically lasts from July to December, the region experiences a high volume of annual rainfall with over $3000 \mathrm{~mm}$. The average monthly temperature and rainfall pattern in Kiangan, Ifugao is shown in Figure 3.

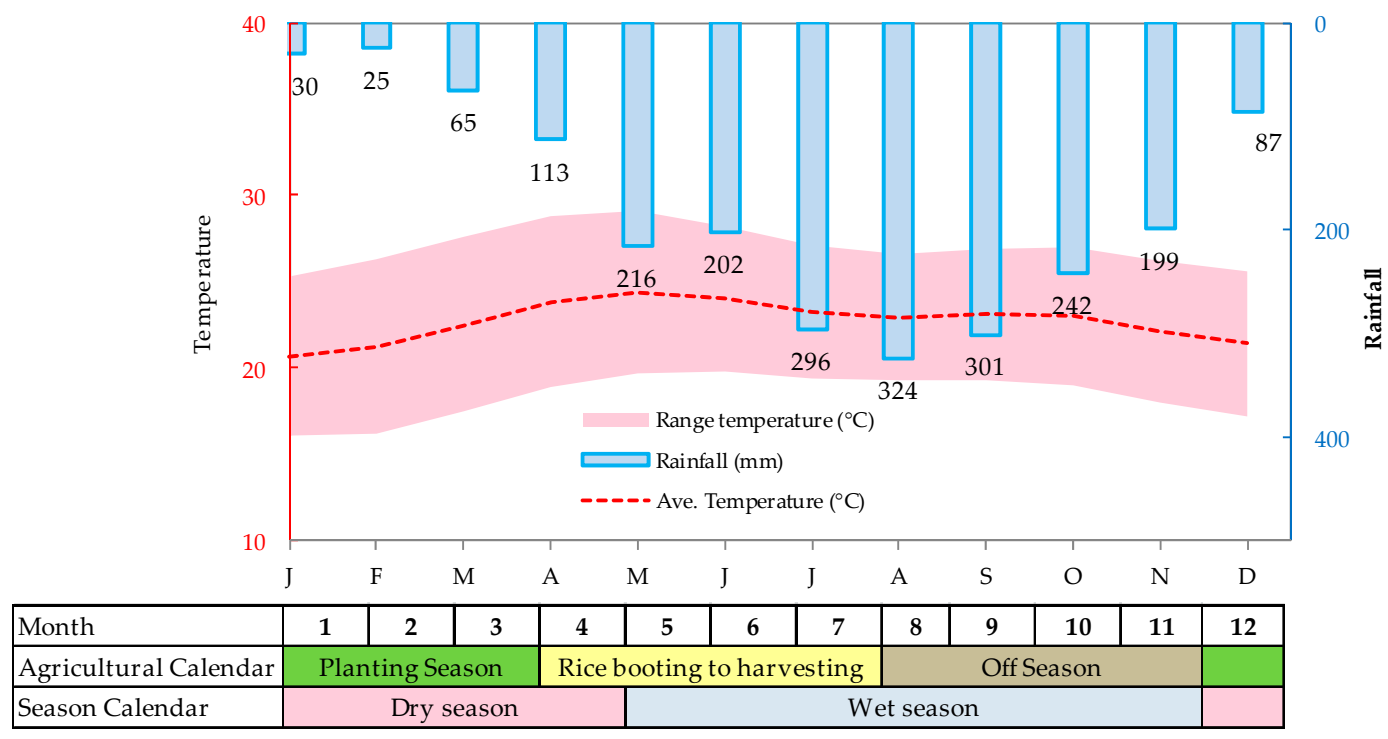

Figure 3. Maximum and minimum temperature in Kiangan, Ifugao and agricultural calendar (climate data were collected from the Philippines climate data). 


\section{Ifugao Land Management System}

In Ifugao, the land use classes can be categorized into five main groups, as shown in Figure 4 and Table 1. Figure 4a shows the mountain landscape of Ifugao rice terraces with different land use types. Figure $4 \mathrm{~b}$ shows various land management systems in Ifugao and their variation with elevation [26].

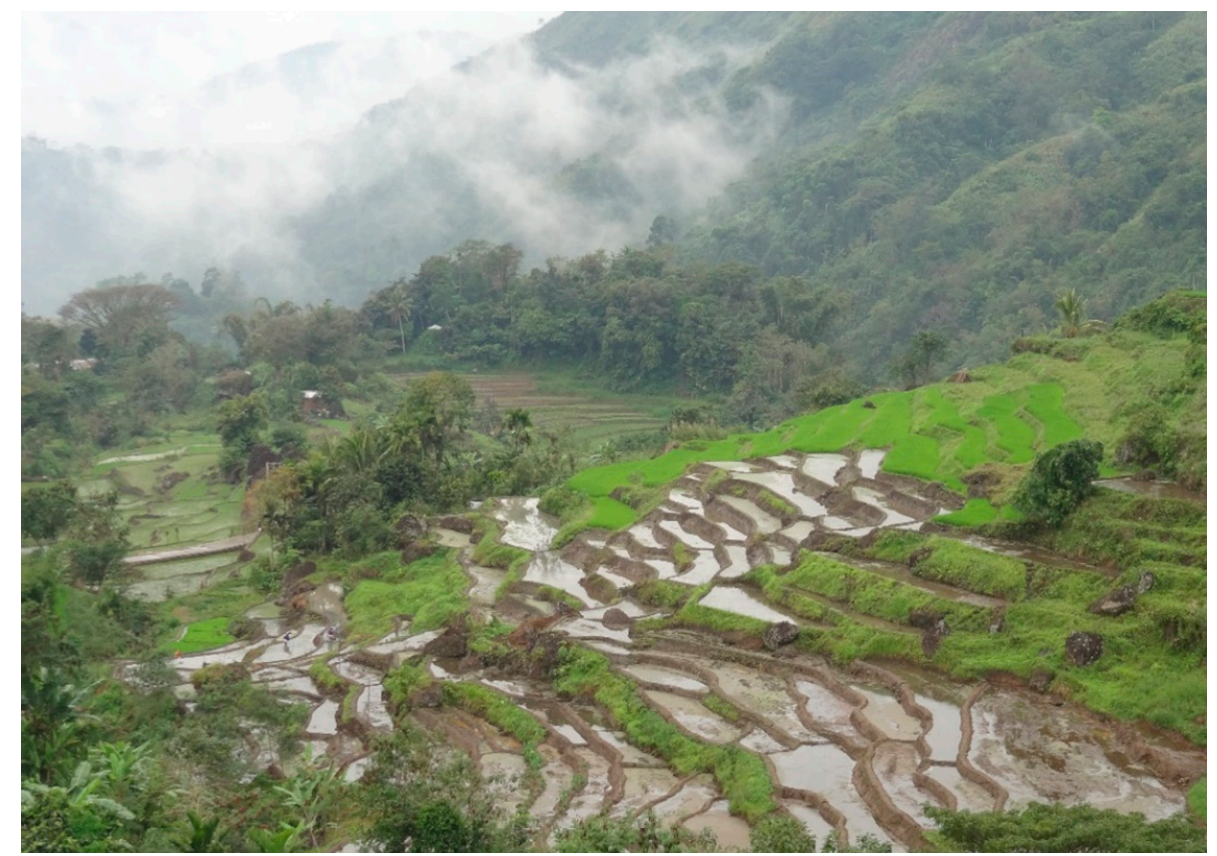

(a)

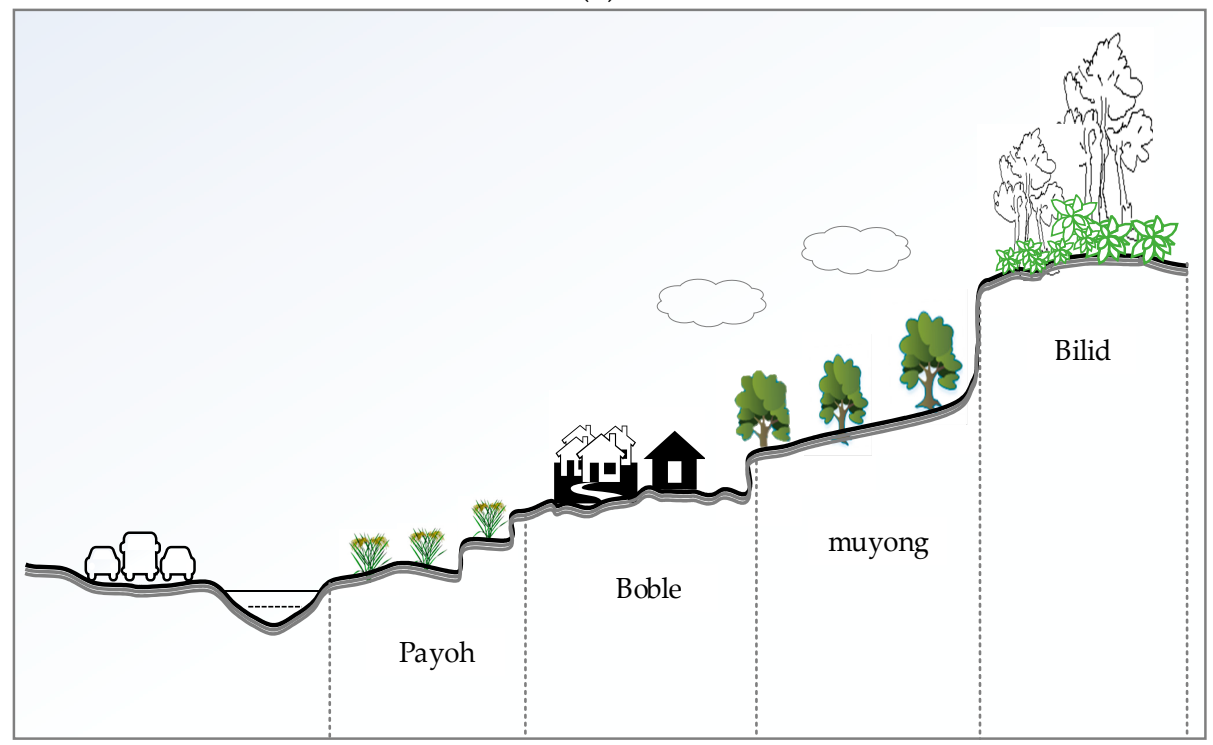

(b)

Figure 4. (a) Mountain landscape of Ifugao rice terraces. (b) Transect shows various land management systems with elevation in Ifugao.

The rice terracing system of Ifugao has existed for thousands of years [28]. The terracing system is remarkable (showing the use of traditional knowledge to sustain complex terraced fields, managed forests, good irrigation systems, and society) for the fact that the residents have managed to cultivate such intricate landscapes with only simple hand tools [29]. The rice terracing system makes use of complementary shifting cultivation, a concept that makes calculated and timely use of the different land types to achieve sufficient food production while mitigating the extent of land degradation. 
The actions guiding the rice terracing system are based on different weather patterns experienced by the community but generally, follow the pattern in Figure 3. Figure 3 shows that the planting season takes place roughly between December and March. After planting is completed, during the dry season, which lasts from late March to mid-June, agricultural work shifts from terrace construction to maintenance. Seed planting in the habal often takes place at the beginning of the dry season. The strain of native rice endemic to this part of Ifugao is known as Tinawon, which is highly regarded in the region. Ifugao traditional beliefs depict the crop as a gift from God. The local farmers are familiar with the tendencies of the crop because of the long history of cultivation. The strain of native rice has been optimized for the traditional method of growing rice, though that method has become less and less prevalent in recent years. This is due to the fact that the cultivation of native rice is notoriously labor-intensive and is not feasible without cooperation from the entire community. In addition, the Tinawon allows only one harvest per year, while commercial rice allows two crops per year [30].

The forest management system native to Ifugao is known as the muyong system. The muyong system refers to the maintenance schemes that are employed in the private woodlots known as muyong. The muyong system is a completely self-initiated and self-regulated approach to forestry management that has been institutionalized into the local culture. It has been recognized as a complex and rich ecosystem that provides a wide range of ecosystem services [31]. The underlying principle behind the muyong system is grounded in the idea that taking care of the muyong is necessary because it provides water to the rice terraces. It instills the idea that without the muyong there can be no rice terraces, thereby making forest preservation essential for one's livelihood.

Table 1. Land use classes in Ifugao.

\begin{tabular}{|c|c|c|c|c|}
\hline Local Name & Description & Location & Slope & Management \\
\hline Payoh & rice field & below muyong & none & Private \\
\hline Boble & settlement & $\begin{array}{l}\text { in-between payoh } \\
\text { and muyong }\end{array}$ & none & Private \\
\hline muyong & private woodlot & $\begin{array}{l}\text { above terraces, } \\
\text { adjacent to home }\end{array}$ & high & Private \\
\hline Habal & agricultural land & distant from home & high & Private \\
\hline Bilid & public forest & distant from home & high & Communal \\
\hline
\end{tabular}

\section{Methodology}

Figure 5 shows the study process on maintaining traditional rice terraces and forest restoration in the Ifugao. Initially, desk study was conducted to review previous papers and design the process of study to conduct qualitative research. The desk study was useful for the selection of the study site as well as for designing the questionnaire survey. The field survey was conducted from 8-14 February 2015 in the Nagacadan site of Ifugao. The study intended to carry out a questionnaire survey among farmers living within the study site to quantify their engagement with the muyong and the problems perceived in their society. However, this approach was changed to a focus group discussion and key informant interviews due to the busy schedules of the farmers coupled with the lack of time and issues with the language barrier. 


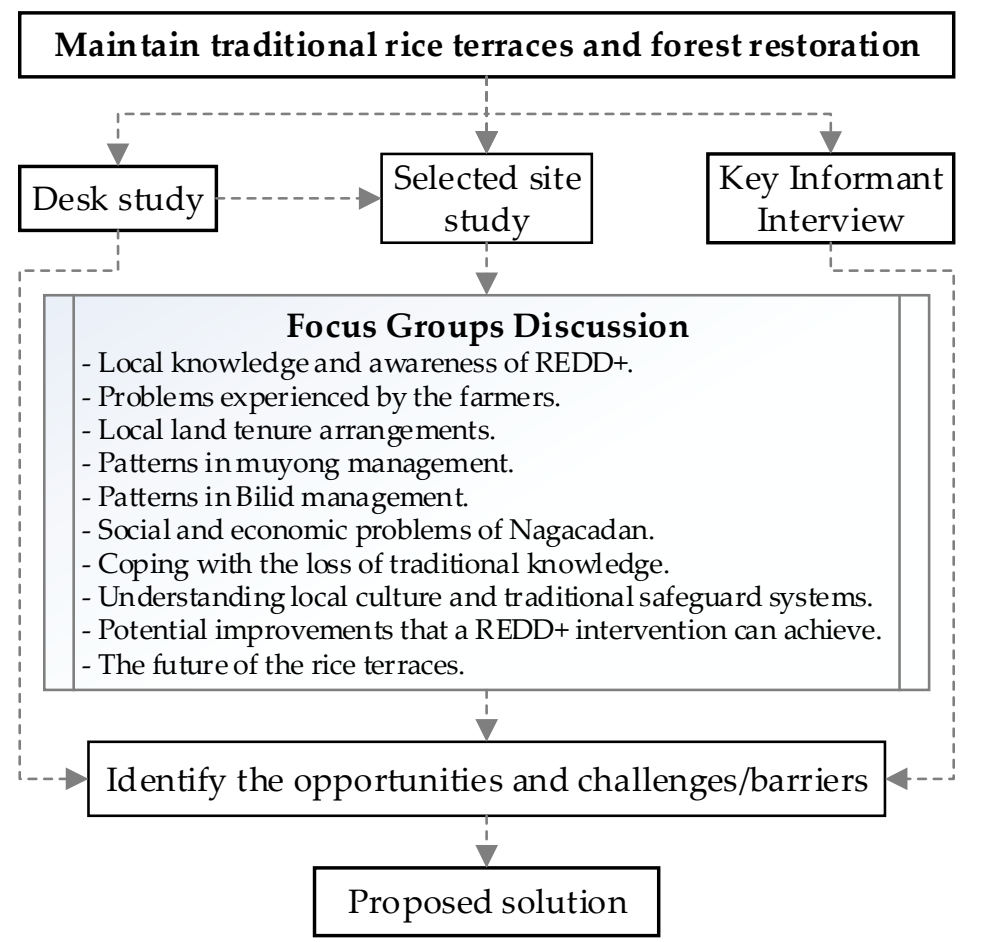

Figure 5. Chart of study progress to maintain traditional rice terraces and forest restoration.

\subsection{Focus Groups Discussion (FGD)}

The desk study was useful for designing questions for the FGD. The focus group discussion was based on the opinions of members including local farmers, university professors, the community head and members of the local community. The participants were divided into two groups based on the age-in the first group, the participants' age were less than 40 years old, and in the second, whose age is over 40 years. During 90 min of FGD, the facilitator guided the discussion in terms of the following section, as shown in Figure 5. The main questions designed for the FGD to evaluate the potential of implementing REDD+ intervention in the muyong in terms of forest restoration (Figure 5), starting with assessing the local people's awareness towards REDD+ and trying to estimate the opportunity and transaction costs of staging a REDD+ intervention. We also tried to assess the role of muyong in the current scenario and how REDD+ intervention affects the local community people.

\subsection{Key Informant Interview (KII)}

The information obtained from KII also supplemented the information used to identify the opportunities and challenges of REDD+ implementation. With the same contents as those asked during the FDG, in-depth discussions can propose some recommendations for solving issues in the muyong forest. The KII technique can provide more information from a wide range of people. In this study, individual interviews with seven key informants which included university professors, farmers, and members of local non-governmental organizations (NGOs), officers from Ifugao Cultural Heritage Office (ICHO), business owners, the head of the tourism department, and hosts at local homestays were selected. The key informant interviews and focus group discussions were used to assess the problems in the area and to find out whether a REDD+ intervention could be beneficial to the area or not. 


\section{Results and Discussion}

\subsection{Situation of Rice Terraces and the Role of the Muyong Forest}

REDD+ intervention is expected to enhance forest resources, ecosystem services and co-benefits to the local people. The Ifugao rice terraces are going through several economic, social, and environmental issues. In this section, we discussed the situation of Ifugao: (1) livelihoods at risk due to the declining rice terrace under urbanization and industrial development; (2) the integrity of the family unit due to emigration of women and youth for high income and education, and (3) the use of commercial rice enhancing the use of pesticides. Figure 6 shows the situation of economic, environmental and societal issues in the study area. Later, we discuss the opportunities and potential challenges to REDD+ intervention in Ifugao.

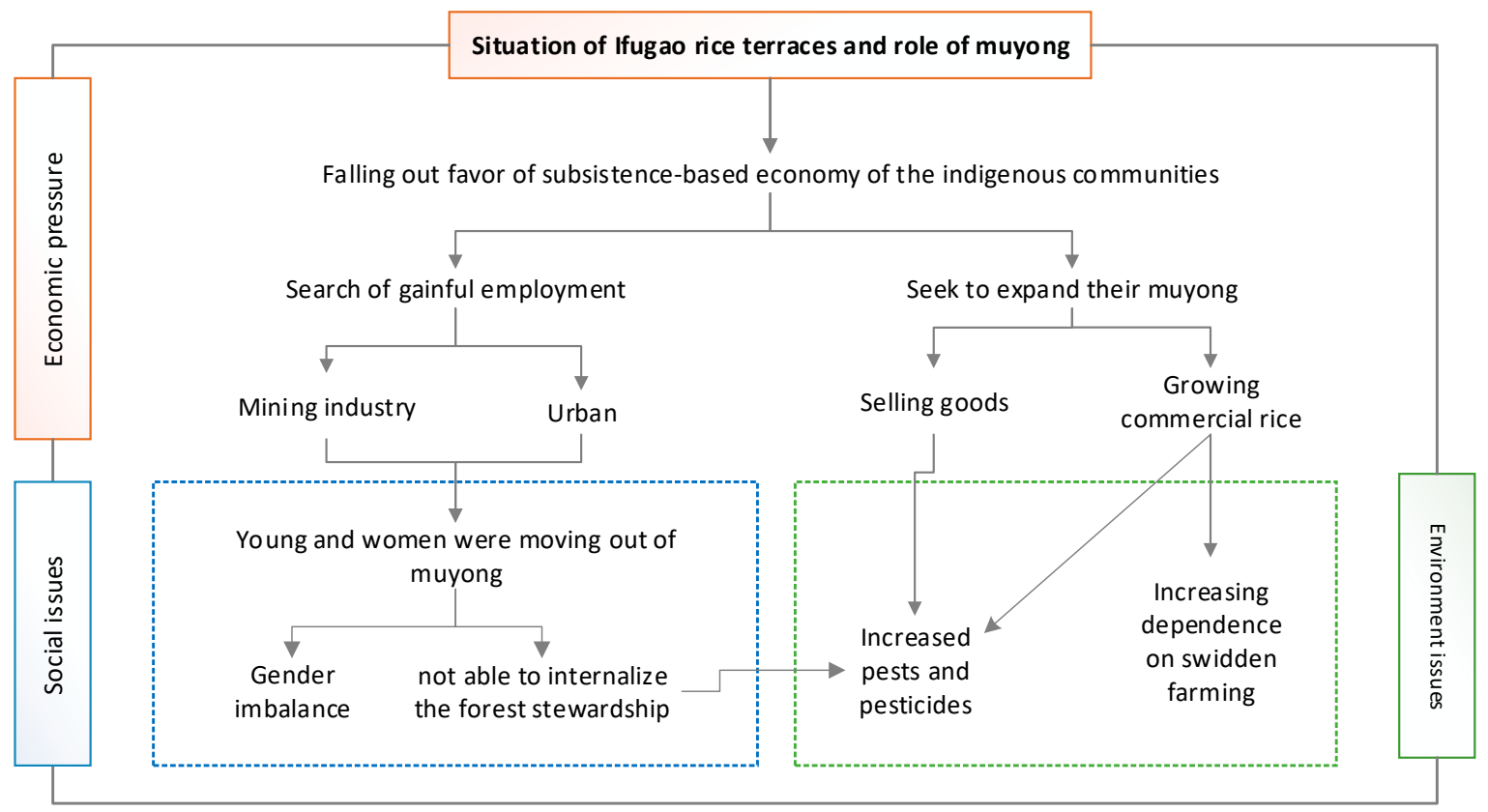

Figure 6. of Economic, environmental and societal issues in the study area.

\subsubsection{Economic Issues}

Figure 6 shows the situation of Ifugao rice terraces and the role of muyong. Rice terraces in Ifugao are under economic pressure due to the external pressure experienced in Ifugao. The increased economic activity in the Philippines and ongoing modernization of the domestic economy is driving greater necessity for monetary income in daily life. Thus, the subsistence-based economy of the indigenous communities is largely falling out of favor, a view that is particularly prevalent among the youth. Therefore, a situation of on-going declining agricultural production in the rice terrace has been detected since people have gone outside the province in search of gainful employment or in pursuit of higher education.

Besides, many of the younger generation and women are moving to the mining industry, urban centers and modernized locales in search of higher income. In some cases, some farmers have been able to generate extra income by selling goods found in the muyong such as the littuko (rattan fruit), and the moma (betel nut). The introduction of commercial rice, which is easy to plant with high yields, causes a change in the cropping patterns and affects traditional rice growth and traditional knowledge. The traditional belief is that the women are better in planting the native rice. Since the introduction of commercial rice, men have been able to participate in planting, due to the more resistant nature of the commercial rice. This has led to a change in paid labor schemes within the terraces, where men are paid more than women because they are perceived to be able to plant faster than women [32]. 
The FGD showed that the high percentage of female migration as compared to males in search of work has led to changes in labor roles, which is indicative of a shifting gender balance. These conditions are serving to marginalize the role of women in the terrace society and indirectly contributing to the outward migration of women.

\subsubsection{Social Issues}

The rapid rate of economic growth is also expected to put pressure on the natural environment, as pressures from growing industrial sectors will look to draw upon the country's vast natural resources. One of the issues threatening the future of the rice terrace system is a growing perception among the youth that the rice terracing lifestyle is tedious and overly labor-intensive. The modernization of Ifugao has created a growing rift between the relatively modern youth and the conservative traditional population, which hinders the effective transfer of indigenous knowledge and is leading to outward migration (Figure 6). For the young people in Ifugao, the need for monetary income is not the only driver but is reflective of changing societal values and perceptions of the growing opportunity cost of farming the terraces. The emigration of families has resulted in families relocating to the neighboring provinces of Quirino, Isabela, Nueva Vizcaya, and Baguio. Simultaneously, there is not much inward migration as the societal system renders land in the barangay difficult for outsiders to obtain. The greater opportunities that are available outside the region are making it more difficult for individuals to forgo participation in the formal economy. The practice of remittances is not popular within the community because the older members in the community consider those who receive money from remittance as lazy people. Nevertheless, the difficulty of the rice terracing lifestyle has increased the number of instances of land abandonment within the area. The emigration of skilled residents is creating ripple effects within the society, as the loss of skilled people reduces both the quality and supply of labor in the area. Therefore, it increases the level of difficulty for those that remain in the terraces, contributing to the negative perception of the rice terraces. Emigration also threatens to alter the gender balance of the community, with generally more men remaining to farm the terraces than women. This has terrible outcomes on the integrity of the family unit. Furthermore, the disinterest in traditional practices among the youth is serving to marginalize the role of elderly women in the traditional society who often are the keepers of traditional knowledge. The outward migration of the youth and their shunning of traditional knowledge pose a key long-term threat to the sustainability of the terraces. Some respondents have cited the lack of patience in terracing among youth participants to be a key impediment to the knowledge transfer process; indicative of a change from the traditional way of thinking. Ultimately, the impending crisis that this society faces is that the highly valuable traditional knowledge and concept of forest stewardship are likely to erode with the flight of the young, who have not grown up with similar values as the elders in the village.

\subsubsection{Environmental Issues}

The increasing use of commercial strains of rice is facilitating a great deal of the internal changes, as witnessed in Ifugao. Farmers continue to incorporate commercial rice because of its high productivity, as the use of commercial rice varieties allows two harvests compared to the single harvest offered by native Tinawon rice. By doing so, they have been able to fulfill their dietary requirements; however, the intensive use of commercial rice is not only serving to degrade the terraces, but is also exerting a transformative effect on the entire agricultural system. Moreover, with any form of food production, there are several pests that disrupt the agricultural system. Earthworms, birds, and field rats among others, have a long history of plaguing the terracing system. In the past, farmers have used traditional fertilizers and practices to mitigate the damage caused by pests; however, pests associated with commercial strains of rice are fundamentally changing the way that the community approaches the idea of pest management as they switch to more intensive use of commercial pesticides to deal with these pests. Particularly aromatic strains of rice are capable of attracting more pests to the terracing area. Hence, other farmers must also depend on the use of chemical pesticides, which may influence 
the effective functioning of the agricultural system. These actions exert a positive feedback loop that is causing greater numbers of farmers to alter their behavior and further change the nature of the terracing system. Furthermore, the more frequent plantings of commercial rice serve to further increase methane emissions by the rice terraces [33]. Recently, in response to increasingly difficult farming conditions and unreliable weather, the farmers in Nagacadan have expressed the desire to expand their agricultural land in order to ensure the stability of their harvest, but these desires have been deterred by the national government's strict policies on logging and the cultural taboo of forest conversion. Though there is currently adequate food production, greater demand for swidden land in the future may cause friction against the traditional belief of forest protection. Much of the evidence reveals that some problems, both external and internal, are making it difficult for the rice terraces to continue to thrive within the context of a modernizing world. A lot of the newer problems seem to stem from the introduction of commercial rice to the area, and towards protecting the traditional way.

\subsection{Opportunities and Potential Barriers and Challenges to REDD+ Intervention}

The muyong system is an effective climate change mitigation strategy as the practices employed in muyong forest management enable greater carbon sequestration, degradation prevention, and co-benefit creation. The future existence of the muyong and the rice terracing system is under threat. These threats have created an opportunity for REDD+ in the area. The muyong system can gain various opportunities under the REDD+ mechanism. Local communities within the study site can play a major role in forest conservation. These community people can serve as guardians of the forest to prevent illegal logging and earn carbon credits. A previous study found that the muyong has high carbon stock when compared to other land use types in the area [34]. Therefore, the implementation of REDD+ in muyong has high potential in the study area. However, it is also important to estimate the cost of monitoring and implementing REDD+ because previous studies have demonstrated that the cost of monitoring and implementing REDD+ varies with the study site and area. The opportunity cost of conserving the forest is the main component of REDD+ and used for regional and global estimates of REDD+ costs [35]. Kindermann et al. [36] estimated that the global opportunity cost of curbing deforestation rates by $10 \%$ in Southeast Asia by 2030 would be $2-8 \mathrm{US} \$ / \mathrm{tCO}_{2}$ and that of a $50 \%$ reduction would be $8-38 \mathrm{US} \$ / \mathrm{tCO}_{2}$.

Based on the results of the FGD and KII, REDD+ intervention has the potential to contribute towards sustainable forest management in Ifugao. However, the participation of local communities is important for project design and to avoid conflict at a later stage. Therefore, project introduction and cooperation building are important before starting the project. The project should also provide capacity building opportunities for local people to strengthen forest protection and management [37]. It is intended that REDD+ activities should be aligned with muyong forest management to ensure co-benefits by improving livelihood, biodiversity conservation, enhancing ecosystem services, and watershed protection.

The results from the FGD shows the opportunities of a REDD+ project can help the local/indigenous people. Also, REDD+ improves the support that the local government receives from the national government. The KII revealed that REDD+ intervention should be built upon the preservation of traditional knowledge by strengthening the community's people. Furthermore, REDD+ should find ways to improve the living standard of indigenous communities and they should feel pride among the communities.

\subsubsection{Potential Challenges to REDD+ Intervention}

The potential implications of a REDD+ intervention, such as the active promotion of the muyong, present risks of upsetting the natural environment. Although the muyong and the bilid are both forested areas and the present study has focused on the muyong, there are still concerns about promoting the muyong over the bilid. For instance, there is a variation in tree species of the muyong and bilid, which can be a result of many factors such as the selective cutting and facilitated growth practices 
that are employed in the muyong and the elevation of the forest. The bilid forest is located at a higher elevation than the muyong and is exposed to more sunlight. The concept of community-based forest management (CBFM) will be more appropriate for the bilid as compared to the muyong. The use of agroforestry and selective growing of food in the muyong can potentially upset the species composition of the forest, which has the potential to introduce new species of pests. We noted that, generally, all land uses are considered important as they provide benefits in some way or other, and care must be taken so as not to prioritize the promotion of one land use over another.

One of the most challenging aspects of designing a REDD+ project is finding ways for the project to continue to bring benefits even after the completion of the project. It has often been the case that despite a monitored improvement during the project timeline, after the project funding ends, people revert to their old destructive ways or, sometimes, a bad situation after the completion of the project. One way to ensure the continued sustainability of a project is the targeting of co-benefits [38]. One of the possible solutions being considered is the expansion into a coffee plantation as they were able to grow coffee trees in the muyong. Another possibility would be tapping into the organic market, which is expected to grow in the future due to the improving economic situation in the Philippines. As most of the food that is grown in Ifugao has traditionally been organic, the area also practices the raising of free-range chicken; however, there may be some conflict with trading livestock as up until now they have only been raised for domestic consumption. Moreover, the attempts to instill pride in the indigenous youth through education programs have yet to yield appreciable results. Traditional knowledge appears to form the backbone of the societal values and practices, of which respect and preservation of the muyong is a vital part. In a sense, the implementation of a REDD+ project is in itself an acknowledgment of the responsible forestry practices that they have developed. Another challenge that REDD+ might face is a governance structure which considers equitable benefit sharing among the community's people.

\subsubsection{Potential Barriers to REDD+ Intervention}

In the future, REDD+ intervention may become feasible and make a positive impact on muyong forest. However, the nascent phase of development, capacity, and social issues constitute significant barriers to the establishment of REDD+.

- Capacity issues

One of the barriers that can prevent the movement of the REDD+ process in Ifugao is the lack of capacity among local institutions. It is, however, not expected to be an extreme hindrance to a REDD+ intervention in the area. Through existing initiatives such as the Globally Important Agriculture Heritage Systems (GIAHS) program, local government offices have had some experience in coordinating with international organizations. Some gaps that could potentially complicate an intervention were highlighted. The most glaring would be the potential for corruption and inefficiencies resulting from the disconnected interactions between the government and the local communities. Previous studies also reported corruption issues in REDD+ implementation in the Philippines [39]. On a national scale, the lack of appropriate auditing mechanisms specific to the forestry sector has been well documented. On the project-scale however, this risk can be mitigated.

- Socioeconomic risks

The FGDs and KIIs verified that the local people have somewhat low regard for government policies. They tend to view them as ineffective, which has led to them not being eager participants in government-introduced projects. This is consistent with the notion of Nagacadan as a fairly insular community, which makes it difficult for foreign actors to intervene; that being said, there is a substantial amount of foreign support and attention paid to the area, as evidenced by the United Nations Educational, Scientific and Cultural Organization (UNESCO) inscription and the GIAHS program. Fortunately, they have generally policed themselves with autonomy, which has hitherto 
worked for them. Furthermore, their scrutinizing view of outsiders and their interventions has served to insulate them from typical socioeconomic temptations and pressures that most rural communities face. The elder population appears to possess a more suspicious view on the role of money in society. This comes from a culture with a long history of self-sufficiency and subsistence; however, the generation gap exhibits a significant difference in attitude towards the role of money in society. Even though it is now a common national custom, the sending of remittances is still somewhat discouraged among the local community, who view handouts as an indication of "laziness". That being said, there is a substantial possibility for this paradigm to fade away as the role of money continues to increase in modern Ifugao society.

- Land tenure requirements

One of the most significant challenges to REDD+ intervention in the area would be the lack of clear land tenure agreements. The community has largely been able to set its own rules for conflict resolution. In Nagacadan, the filing of tax registration forms serve as the primary form of reporting and compliance that constitutes government regulation of muyong ownership. Within this tax registration system, farmers are required to file tax declarations indicating the size of their muyong in order to avail muyong resource permits, which legally allow them to obtain timber resources from the muyong. The tax registration forms are essential declarations of ownership, which have to be endorsed by the barangay leaders. However, at the moment, there are no other forms of verification that exist within this system. The result is that this reporting method is not regarded as accurate among the community members because farmers have a tendency to under-declare their holdings. Thus, a gap exists between the legal ownership of muyong in the area and the local community's understanding of the boundaries. Though the terraces have functioned without conflict until now, a REDD+ intervention has to take into account this existing system in order to allow equitable benefit sharing and prevent outcomes such as elite capture by well-informed members of the community.

- Establishing Community Participation

Another challenge would be the lack of awareness of REDD+ among the community people. Within the focus group discussions, none of the participants admitted to knowing about the purpose or function of REDD+, though many were easily able to process and articulate the fundamental concept of climate change. On the other hand, the local NGO Save the Ifugao Terraces Movement (SITMO) has considerable influence as it has many interactions with the area, and several of its key members reside in the community or in nearby settlements. Furthermore, several of its members are able to converse in the local dialect. Thus, one recommendation would be utilizing SITMO as they possess key tools that are necessary for effective knowledge transfer and community participation. It is also necessary that the creation of a venue that enables community interaction, given that gatherings are fairly uncommon events due to the busy schedules of the farmers. Any large gathering would likely need to be well organized and feature content that the stakeholder deems relevant to their situation.

- Social impact

Despite the existence of projects targeted at education for sustainable development (ESD) and indigenous knowledge transfer such as the GIAHS initiatives, we still see that despite the availability of this form of knowledge transfer, there is a lack of interest among the youth. Most of the village and SITMO echoed the sentiment that the westernization of education had the effect of disregarding traditional knowledge, which has served to draw younger generations away from Ifugao. In recent years, ESD has attempted to resolve this issue by making such knowledge more available but has had limited success due to methodological issues with the dissemination of this knowledge. Many of the youth find the ESD concepts taught in a formal education setting to be irrelevant. Noting the lack of an indigenous youth group in the stakeholder identification process, it would be useful and important to find a way to better integrate the younger generation in decision making. 
- Risks of reversals

There are serious concerns as to how the community would respond to a REDD+ intervention. The method of intervention is the primary concern. As the Ifugao have already traditionally valued and maintained the forests for free, there is the risk that if the project is not properly structured, this could pervert the existing values that the Ifugao have placed on the forest, such as leading farmers to disregard the forests when they are not receiving compensation. There is a need to assess the problem with a long-term mindset. However, it is easy to consider that outward migration and decreased human interaction could simply allow the muyong to regenerate naturally. This may be true for a time but comparing the results of the carbon study from the muyong to the lack of intervention in the bilid, the muyong clearly is more effective at sequestration [34]. Furthermore, the outward migration of people threatens more than the loss of forest carbon; it also threatens the loss of knowledge that the indigenous communities have spent thousands of years building.

\subsubsection{Maintenance of the Muyong}

The challenges in REDD+ development of many countries are agreement design between the government and communities [40]. Bolin et al. [41] reported the REDD+ challenge in Tanzania in 2012 to develop forest management strategies that meet the poor's needs, for future generations; thus, the planning of land use, conservation, and agroforestry practices leading to ensure the permanence of the REDD+ mechanism in Tanzania. Previous studies have reported that community forestry can lead to an increase in forest cover in areas where low forest cover present [42-44]. There are some studies that have demonstrated that the recognition of community property rights over a forest [45], as well as secured tenure arrangements, leads to a decrease in deforestation [46] and helps the implementation of REDD+. In the muyong case, one approach to maintain the muyong system would be to alter the forest management system to target greater opportunities for income generation for the local people. It can be done through the promotion of commodity goods and agroforestry in the muyong, initiatives that have already been implemented to some capacity by the GIAHS program, which has introduced a variety of different crops to the area. The potential risks of such programs are a possible negative impact on biodiversity or the introduction of a new invasive species. Nagacadan has been identified as a safe habitat that fosters biodiversity of the avian species. The bird communities stand to benefit from the increased protection of muyong forests. We found another potential would be the integration of muyong farmers into instructor roles, which could serve to improve the scalability of muyong, at least in the project area, and serve to provide those who impart the practices of muyong with a viable source of income. This has been attempted to some extent by the GIAHS master program. The purpose was to facilitate knowledge transfer and development of traditional knowledge. Rewarding and encouraging local people will be beneficial to the success of REDD+, as previous study in Tanzania rewarded local people for improved forest management [41].

\section{Conclusions}

The muyong appears to be an effective forest management system under the framework of REDD+ because human intervention helps the forests to sequester greater amounts of carbon than if the forest were left alone. In addition to sequestering carbon, the system provides protection against deforestation, creates co-benefits through the integration of agro-forestry practices, and promotes biodiversity. However, the situation in Ifugao is likely to change due to mounting economic pressure on the local communities. These societal changes are altering the perceptions of the youth, causing them to value the traditional practices less and less, threatening the sustainability of the terraces in the long-term. Furthermore, the integration of commercial rice is changing the traditional agricultural system and placing less focus on forest maintenance. A REDD+ intervention could be helpful to this area by helping local communities find new innovative ways to maintain their system while coping with the modernization of the Ifugao economy. There is a need for a paradigm shift in which people 
perceive forests as essential for the long-term sustainability of society. REDD+ is the vehicle by which we can control the challenges presented by increasing requirements of forests. Forests should be valued not only for the carbon sequestration but also because they serve as a living embodiment of the traditional forest management practices in the area. The loss of traditional knowledge threatens to undo thousands of years of experiential learning. The implementation of REDD+ in the muyong system will be a win-win action for the local community because both share the objective of managing the forest sustainably. Good forest governance and strong stakeholder collaboration are needed for the success of a REDD+ intervention.

Author Contributions: Conceptualization, R.A., K.T., S.H.; methodology, K.T.; formal analysis, R.A., K.T., S.H.; investigation, R.A., K.T., S.H.; writing-review and editing, R.A., K.T., S.H.

Funding: Asia-Pacific Network for Global Change Research (ARCP2011-13NMY-Herath).

Acknowledgments: The authors are thankful to the Asia-Pacific Network for Global Change Research (ARCP2011-13NMY-Herath) for supporting the field research. The authors would like to thank The Ifugao State University (IFSU), NGO Save the Ifugao Terraces Movement (SITMO), Ifugao Cultural Heritage Office (ICHO), tourism department and Ifugao people for participating in focus group discussion and in key informant interview. We are also thankful to Dixon Tuzon Gevana, Diwa Johanna Paula and Ashwani for their supports and suggestions.

Conflicts of Interest: The authors declare no conflict of interest.

\section{References}

1. Licyayo, D.C.M. National Policies and Local Ordinances on Ifugao Rice Terraces. Int. J. Ecol. Conserv. 2013, 8, 30-43. [CrossRef]

2. Avtar, R.; Kumar, P.; Oono, A.; Saraswat, C.; Dorji, S.; Hlaing, Z. Potential application of remote sensing in monitoring ecosystem services of forests, mangroves and urban areas. Geocarto Int. 2017, 32, 874-885. [CrossRef]

3. Avtar, R.; Suzuki, R.; Sawada, H. Natural Forest Biomass Estimation Based on Plantation Information Using PALSAR Data. PLoS ONE 2014, 9, e86121. [CrossRef]

4. Avtar, R.; Suzuki, R.; Takeuchi, W.; Sawada, H. PALSAR $50 \mathrm{~m}$ Mosaic Data Based National Level Biomass Estimation in Cambodia for Implementation of REDD+ Mechanism. PLoS ONE 2013, 8, e74807. [CrossRef] [PubMed]

5. FAO. In Global Forest Resources Assessment 2015 Country Report Philippines. Forestry Department Food and Agriculture Organization of the United Nations 2015, 164, 5.

6. Philippines Overview. The World Bank in the Philippines. Available online: https://www.worldbank.org/en/ country/philippines/overview (accessed on 2 August 2019).

7. Tumaneng-Diete, T.; Ferguson, I.S.; MacLaren, D. Log export restrictions and trade policies in the Philippines: Bane or blessing to sustainable forest management? For. Policy Econ. 2005, 7, 187-198. [CrossRef]

8. Gálvez Nogales, E.; Webber, M. Territorial Tools for Agro-Industry Development; FAO: Rome, Italy, 2017.

9. Kiyono, Y.; Saito, S.; Takahashi, T.; Toriyama, J.; Awaya, Y.; Asai, H.; Furuya, N.; Ochiai, Y.; Inoue, Y.; Sato, T.; et al. Practicalities of non-destructive methodologies in monitoring anthropogenic greenhouse gas emissions from tropical forests under the influence of human intervention. Jpn. Agric. Res. Q. 2011, 45, 233-242. [CrossRef]

10. LEAD, U.L.E.A.D.P. Current Challenges and Priorities for Greenhouse Gas Emission Factor Improvement in Select Asian Countries; USAID Low Emissions Asian Development (LEAD) Program: Washington, DC, USA, 2013; AID-486-C-11-00002, 101.

11. World, T. Climate Change, Agriculture, Developing Countries: Does Adaptation and matter. World Bank Res. Obs. 2011, 14, 277-293.

12. Soriano, M.A.; Diwa, J.; Herath, S. Local perceptions of climate change and adaptation needs in the Ifugao Rice Terraces (Northern Philippines). J. Mt. Sci. 2017, 14, 1455-1472. [CrossRef]

13. Dizon, J.; Calderon, M.; Sajise, A.; Andrada II, R.; Salvador, M. Youths' Perceptions of and Attitudes Towards the Ifugao Rice Terraces. J. Environ. Sci. Manag. 2012, 15, 52-58.

14. Acabado, S. The Ifugao agricultural landscapes: Agro-cultural complexes and the intensification debate. J. Southeast Asian Stud. 2012, 43, 500-522. [CrossRef] 
15. Taguiling, N.K. Macrofloral Biodiversity Conservation in Ifugao. Eur. Sci. J. 2013, 4, 469-482.

16. Nozawa, C.; Malingan, M.; Plantilla, A.; Ong, J. Evolving culture, evolving landscapes: The Philippine rice terraces. Prot. Landsc. Agrobiodivers. Values 2008, 1, 71-93.

17. Jang, J.W.; Salcedo, S. The socio-political structure that regulates the Ifugao Forest Maintenance. In Proceedings of the 4th International Conference on Biology, Environment and Chemistry (IPCBEE), Phuket, Thailand, 10 September 2013; Volume 58, pp. 85-94.

18. Mallak, S.K.; Elfghi, F.M.; Rajagopal, P.; Vaezzadeh, V.; Fallah, M. Overview of waste management performance of industrial sectors by selected Asian countries: Current practices and issues. Int. Proc. Chem. Biol. Environ. Eng. 2016, 99, 66-75.

19. Rabena, M.A.F.; Macandog, D.M. Contemporary Knowledge of Woodlot (Muyong) Resource Management: A Case Study of Key-Informants Perceptions in Brgy. Kinakin, Banaue, Ifugao, Philippines. J. Manag. Dev. Stud. 2017, 6, 14-21.

20. Center for International Forestry Research Community-Based Forest Management Key to Success of REDD+. Available online: https://www.cifor.org/press-releases/community-based-forest-management-keyto-success-of-redd/ (accessed on 18 August 2019).

21. Avtar, R.; Sawada, H.; Kumar, P. Role of remote sensing and community forestry to manage forests for the effective implementation of REDD+ mechanism: A case study on Cambodia. Environ. Dev. Sustain. 2013, 15, 1593-1603. [CrossRef]

22. Lasco, R.; Pulhin, F.; Bugayong, L.; Mendoza, M. An assessment of potential benefits to small holders of REDD+ components in the Philippines. Ann. Trop. Res. 2011, 33, 31-48.

23. Bacalla, D.T. Promoting Equity: A Challenge in the Implementation of Community-Based Forest Management Strategy in the Philippines. Hanging in the Balance: Equity in Community-Based Natural Resource Management in Asia. 2006, pp. 162-181. Available online: http://citeseerx.ist.psu.edu/viewdoc/download?doi=10.1.1.567. 1909\&rep=rep1\&type $=$ pdf (accessed on 4 November 2019).

24. Newton, P.; Schaap, B.; Fournier, M.W.; Rosenbach, D.; DeBoer, J.; Whittemore, J.; Stock, R.J.; Yoders, M.; Brodnig, G.; Agrawal, A. Community forest management and REDD+. For. Policy Econ. 2015, 56, $27-37$. [CrossRef]

25. Bouchard, K. Thirsting for Recognition: A Comparative Ethnographic Case Study of Water Governance and Security in the Highlands of Kalinga, Philippines; University of Laval: Québec, QC, USA, 2017.

26. Harold, C.C.; New, H. Ethnographic Atlas of Ifugao: A Study of Environemnt, Culture, and Society in Northern Luzon. Cult. Appl. 1980, 9, 206-208.

27. Bogdanski, A.; Dubois, O.; Jamieson, C.; Krell, R. Making Integrated Systems Work for People and Climate; Food and Agriculture Organization of the United Nations: Rome, Italy, 2010; ISBN 9789251067727.

28. UNESCO. Rice Terraces of the Philippine Cordilleras. Available online: https://whc.unesco.org/en/list/722/ (accessed on 14 August 2019).

29. Martin, M.M. The Rice Terraces of Ifugao Province, Philippines. J. World Herit. Stud. 2017, 1-5. [CrossRef]

30. Camacho, L.D.; Gevaña, D.T.; Carandang, A.P.; Camacho, S.C. Indigenous knowledge and practices for the sustainable management of Ifugao forests in Cordillera, Philippines. Int. J. Biodivers. Sci. Ecosyst. Serv. Manag. 2016, 12, 5-13. [CrossRef]

31. Santiago, J.; Buot, I. Conceptualizing the Socio-Ecological Resilience of the Chaya Rice Terraces, a Socio-Ecological Production Landscape in Mayoyao, Ifugao, Luzon Island, Philippines. J. Mar. Isl. Cult. 2018, 7, 107-126. [CrossRef]

32. Acabado, S.; Martin, M.; Lauer, A. Reports from the Field: The Ifugao Archaeological Project. 2015, pp. 54-61. Available online: https://www.ifugao-archaeological-project.org/uploads/6/4/4/7/6447606/2015bd15_acabado.pdf (accessed on 2 September 2019).

33. FY2013 Global Development Alliance (GDA) Annual Program; Washington, DC, USA, 2014; pp. 1-36. Available online: https://www.usaid.gov/sites/default/files/documents/1880/2013_GDA_APS.pdf (accessed on 4 September 2019).

34. Herath, S.; Tsusaka, K.; Diwa, J. Assessment on the Feasibility of REDD+ in Nagacadan Rice Terraces of Ifugao and Its Muyong Forest; United Nations University Institute for the Advanced Study of Sustainability: Tokyo, Japan, 2015. 
35. Rendón Thompson, O.; Paavola, J.; Healey, J.; Jones, J.; Baker, T.; Torres, J. Reducing emissions from deforestation and forest degradation (REDD+): Transaction costs of six Peruvian projects. Ecol. Soc. 2013, 18, 17. [CrossRef]

36. Kindermann, G.; Obersteiner, M.; Sohngen, B.; Sathaye, J.; Andrasko, K.; Rametsteiner, E.; Schlamadinger, B.; Wunder, S.; Beach, R. Global cost estimates of reducing carbon emissions through avoided deforestation. Proc. Natl. Acad. Sci. USA 2008, 105, 10302-10307. [CrossRef] [PubMed]

37. Lasco, R.D.; Mallari, N.A.D.; Pulhin, F.B.; Florece, A.M.; Rico, E.L.B.; Baliton, R.S.; Urquiola, J.P. Lessons from early REDD. Int. J. For. Res. 2013, 2013, 769575.

38. Angelsen, A. Realising REDD+: National Strategy and Policy Options; CIFOR: Bogor, Indonesia, 2009; ISBN 6028693030.

39. Mayo-Anda, G. Tackling corruption for governing REDD in the Philippines. U4 Issue 2011, 4, 17.

40. Larson, A.M.; Brockhaus, M.; Sunderlin, W.D.; Duchelle, A.; Babon, A.; Dokken, T.; Pham, T.T.; Resosudarmo, I.; Selaya, G.; Awono, A. Land tenure and REDD+: The good, the bad and the ugly. Glob. Environ. Chang. 2013, 23, 678-689. [CrossRef]

41. Bolin, A.; Mustalahti, I.; Boyd, E.; Paavola, J. Can REDD+ reconcile local priorities and needs with global mitigation benefits? Lessons from Angai Forest, Tanzania. Ecol. Soc. 2012, 17, 16.

42. Tan, N.Q.; Thanh, T.N.; Tuan, H.H.; Yasmi, Y.; Enters, T. Red Books for Greener Trees: Strengthening Community Forestry in Vietnam. Forest 2009, 2, 2-4.

43. Roe, D. Linking biodiversity conservation and poverty alleviation: a state of knowledge review. CBD Tech. Ser. 2010, 55, 71.

44. Pramova, E.; Locatelli, B. Guidebook on Integrating Community-Based Adaptation into REDD+ Projects: Lessons from Indonesia and the Philippines; CIFOR: Bogor, Indonesia, 2013; ISBN 602-1504-24-0.

45. Suyanto, S.; Permana, R.P.; Khususiyah, N.; Joshi, L. Land tenure, agroforestry adoption, and reduction of fire hazard in a forest zone: A case study from Lampung, Sumatra, Indonesia. Agrofor. Syst. 2005, 65, 1-11. [CrossRef]

46. Sunderlin, W.D.; Dewi, S.; Puntodewo, A. Poverty and Forests: Multi-Country Analysis of Spatial Association and Proposed Policy Solutions; CIFOR: Bogor, Indonesia, 2007; ISBN 979-1412-21-9.

(C) 2019 by the authors. Licensee MDPI, Basel, Switzerland. This article is an open access article distributed under the terms and conditions of the Creative Commons Attribution (CC BY) license (http://creativecommons.org/licenses/by/4.0/). 